\begin{tabular}{l|c|c}
\hline ISSN: 0001-5113 & ACTA ADRIAT., & ORIGINAL SCIENTIFIC PAPER \\
AADRAY & $59(1): 35-50,2018$ & \\
\hline \hline
\end{tabular}

\title{
Algal pigments distribution and phytoplankton group assemblages in coastal transitional environment - Boka Kotorska Bay (South eastern Adriatic Sea)
}

\author{
Slađana KRIVOKAPIĆ ${ }^{1}$, Sunčica BOSAK ${ }^{2}$, Damir VILIČIĆ ${ }^{2}$, Grozdan KUŠPILIĆ ${ }^{3}$, \\ Dragana DRAKULOVIĆ ${ }^{4}$ and Branka PESTORIĆ ${ }^{4 *}$ \\ ${ }^{1}$ Faculty of Natural Sciences and Mathematics, University of Montenegro, \\ Podgorica, Montenegro \\ ${ }^{2}$ University of Zagreb, Faculty of Science, Division of Biology, Zagreb, Croatia \\ ${ }^{3}$ Institute of Oceanography and Fisheries, Split, Croatia \\ ${ }^{4}$ Institute of Marine Biology, University of Montenegro, Kotor, Montenegro \\ "Corresponding author, e-mail: brankap@ac.me
}

\begin{abstract}
Phytoplankton assemblages and pigment distribution were determined in the transitional Boka Kotorska Bay. Samples were collected four times from three stations in the inner part of the Bay between April 2008 and March 2009. Microscopic analysis revealed that the phytoplankton was composed of marine diatoms, dinoflagellates, cryptophytes, chlorophytes and coccolithophorids. Aside from fucoxanthin as the dominant biomarker pigment, alloxanthin, 19'-hexanoyloxyfucoxanthin, peridinin and chlorophyll b provided indicative contributions. Fucoxanthin and alloxanthin showed significant correlation with the phytoplankton chlorophyll a biomass throughout the investigated period. In November 2008, the diatoms were outcompeted by coccolithophorids, which probably efficiently absorbed nutrients during a period of their reduced supply. Due to the reduced nutrient input, in the summer, the phytoplankton community in the Bay was composed mostly of marine dinoflagellates, cryptophytes, and chlorophytes.
\end{abstract}

Key words: Pigments distribution, seasonality, Boka Kotorska Bay 


\section{INTRODUCTION}

The presence of pigments and phytoplankton assemblages in water samples, as well as their qualitative and quantitative diversity, depends on the interaction of numerous environmental factors. In particular, pigment quality emerges from the species composition of phytoplankton occurring in a given geographical region and specific season (STÓN et al. 2002). Phytoplankton is known to exhibit rapid responses to changes in environmental conditions and is therefore commonly acknowledged as a bioindicator of environmental seasonal changes (RIMET \& BOUCHEZ, 2012).

The use of adequate pigments to characterize phytoplankton communities has been found to be useful in estimating the numbers of small and fragile cells usually underestimated by other procedures (JEFFREY et al. 1997). Fucoxantin. peridinin, chlorophyll $\mathrm{b}$, zeaxanthin and alloxantin are the main photosynthetic pigment characterizing diatoms, dinoflagellates, chlorophytes, cyanobacteria and cryptophytes, respectively (BARLOW et al., 2008). However, pigment data interpretation can be difficult as some pigments are present in several algal groups (MENDES et al., 2011). For instance, fucoxanthin, which is a major pigment in diatoms, is also present in chrysophytes and prymnesiophytes (WRIGHT \& JEFFREY, 2006).

Automated measurements of pigment concentrations using high-performance liquid chromatography (HPLC) allow for highly reproducible analysis. Many studies have demonstrated a correlation between phytoplankton abundance and pigment biomarkers (AHEL \& TERZIĆ, 1998; CARRETO et al., 2003; VILIČIĆ et al., 2008, AGIRBAS et al., 2017). However, the main issue when using pigments for quantitative taxonomy is the overlapping presence of several pigments in different phytoplankton group. The chemotaxonomic software CHEMTAX was development to overcome this problem (MACKEY et al., 1996; LEWITUS et al., 2005). There is a large amount of literature concerning the use of high-performance liquid chromatography (HPLC) pigment analysis and software CHEMTAX for marine systems
(MANDU et al., 2014; COUPEL et al., 2015; mendes et al., 2015; ARAUJO et al., 2017).

Boka Kotorska Bay is a deeply intended bay located in the southeastern part of the Adriatic Sea, where the effect of anthropogenic impact has been substantial, especially in its inner part (KRIVOKAPIĆ et al.,2011; DRAKULOVIĆ et al., 2016). Studies have been undertaken to investigate the spatial and temporal distribution of physical, chemical and biological oceanographic properties, phytoplankton, nutrients and coloured dissolved organic matter in Boka Kotorska Bay (KRIVOKAPIĆ et al., 2009; CAMPANELLI et al., 2009; KRIVOKAPIĆ et al., 2011; DRAKULOVIĆ et al., 2012; BOSAK et al., 2012; DAUTOVIĆ et al., 2012; MARINI et al., 2015; DRAKULOVIĆ et al., 2016).

The aim of this work is to present, for the first time, the detailed seasonal distribution of particular pigments obtained by HPLC with the distribution of individual phytoplankton groups against the background of changes in physicchemical parameters, in Boka Kotorska Bay (in the SE Adriatic Sea).

\section{MATERIAL AND METHODS}

\section{Investigated area}

The study is focused on the southeast part of the Adriatic Sea; the inner part of Boka Kotorska Bay, Kotor Bay. Boka Kotorska Bay (Fig. 1) is one of the most important transitional areas in the region, from both an environmental and a socio-economic point of view. It is formed by three indented branches. There are two innermost embayments to the southeast and northwest (Kotor and Morinj-Risan Bays, respectively) and Tivat Bay spreading to the south from the narrow Verige Strait. The Kumbor Strait connects Tivat Bay to Herceg Novi Bay and the open Adriatic Sea (BELLAFIORE et al., 2011).

The surface area of Boka Kotorska Bay is $87.3 \mathrm{~km}^{2}$. The total volume of Boka Kotorska Bay is $2.4 \times 10^{6} \mathrm{~m}^{3}$. The inner part, Kotor Bay, comprises $27 \%$ of the area and $26 \%$ of the volume of the whole Bay.

In the study area, there are two small rivers: the Škurda, an active river during the whole year 


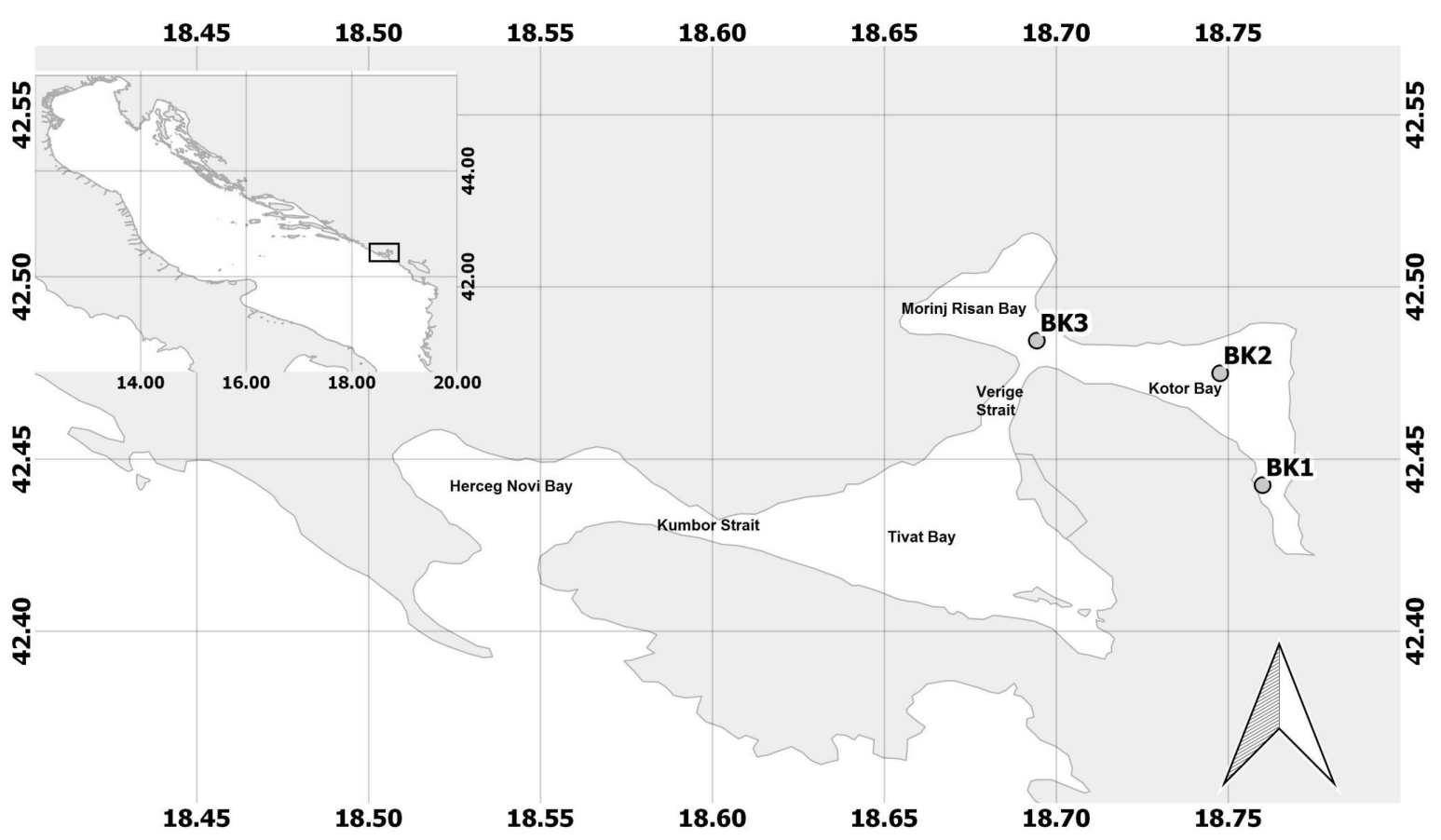

Fig. 1 Map of sampling stations

and the Ljuta, which is active only during the late fall, winter and early spring. The Škurda and the Ljuta empty into Kotor Bay. The discharge of freshwater sources can reach values up to 30 and $330 \mathrm{~m}^{3} / \mathrm{s}$, respectively (BELLAFIORE et al., 2011). Kotor Bay is greatly influenced by freshwater coming from karstic coastal and underwater springs. There is an extremely high annual precipitation quantity; the $4584 \mathrm{~mm}$ it received is Europe's maximum, recorded near Crkvice (IHMZ). Due to its characteristics, the Bay is considered a ROFI (Region of Freshwater Influence)

\section{Sample collection and data analysis}

Seawater samples were taken using a 51 Niskin bottle sampler, from three stations in the inner part of the Bay (see Fig. 1) seasonally in April 2008, July 2008, November 2008 and March 2009. At the innermost station near the Institute of Marine Biology (BK1), samples for physical, chemical and biological analysis were taken from five depths: 0, 2, 5, 10 and $15 \mathrm{~m}$. At the central stations of Kotor (BK2) and Perast (BK3) samples were taken from seven depths: $0,2,5,10,15,20$, and $25 \mathrm{~m}$. The hydrological parameters (temperature and salinity) at BK1 station were taken on a weekly basis from February 2008 to March 2009 (a total of 47 samplings).

Temperature and salinity were measured in situ using a multi LINE P4 - UNIVERSAL METER while an Oxi-Guard Handy GAMMA was use for measuring oxygen concentrations. The nutrient samples were taken using $5 \mathrm{~L}$ Niskin bottles and stored in polyethylene bottles. The determination of nutrient concentrations was done the same day, directly after the sampling. The concentration of nitrates, nitrites, phosphates and silicates were determined using standard methods (STRICKLAND \& PARSONS, 1972). The absorbance readings were made on a Perkin Elmer UV/VIS spectrophotometer (Lambda 2), at different wavelength for each nutrient.

The most prominent biomarkers such as fucoxanthin, peridinin, 19-hexanoyloxyfucoxanthin, alloxanthin, chlorophyll $b$ were chosen to illuminate the temporal and spatial variability of the diatoms, dinoflagellates, coccolithophorids, cryptophytes, chlorophyta respectively (AHEL \& TERZIĆ, 1998; VILIČIĆ et al., 2008). Filters containing phytoplankton were extracted in $4 \mathrm{ml}$ of cold 
Table 1. Taxonomic pigments used in this study

\begin{tabular}{|l|l|l|}
\hline \multicolumn{1}{|c|}{ Phytoplankton groups } & \multicolumn{1}{|c|}{ Phytoplankton pigments / abb } & \multicolumn{1}{c|}{ References } \\
\hline Diatoms & Fucoxantin / fuco & $\begin{array}{l}\text { Ston } \text { et al., 2002; Viličić } \text { et al., 2008; } \\
\text { Vidussi } \text { et al., 2001 }\end{array}$ \\
\hline Dinoflagelate & Peridin /per & $\begin{array}{l}\text { Ston } \text { et al., 2002; Viličić } \text { et al., 2008; } \\
\text { Vidussi } \text { et al., 2001 }\end{array}$ \\
\hline Cryptophyceae & Alloxantin / allo & $\begin{array}{l}\text { Ston } \text { et al., 2002; Viličić } \text { et al., 2008; } \\
\text { Vidussi } \text { et al., 2001 }\end{array}$ \\
\hline Cocolitophorides & Hexa-fucoxantin / hex-fuco & Viličić et al., 2008 \\
\hline Chlorophyta & Chlorophyll $b / \mathrm{chl} b$ & Viličić et al., 2008 \\
\hline
\end{tabular}

$90 \%$ acetone using sonication, and then centrifuged to clarify the extract. The pigments were separated by reversed-phase high-performance liquid chromatography (HPLC) (BARLOW et al., 1993). In short, extracts were mixed $(1: 1 \mathrm{v} / \mathrm{v})$ with $1 \mathrm{M}$ ammonium acetate and injected into a HPLC system incorporating a $\mathrm{C} 183 \mu \mathrm{m}$ Pecosphere column $(3.3 \times 0.45 \mathrm{~cm}$, Perkin Elmer $)$. A binary linear gradient was used to separate the pigments. Solvent A consisted of 80:20 (v/v) methanol: $1 \mathrm{M}$ ammonium acetate and solvent B contained 60:40 (v/v) methanol:acetone. Chlorophyll and carotenoids were detected by absorbance at $440 \mathrm{~nm}$ (Spectra Physics, Model UV 2000). Qualitative and quantitative analysis of the individual pigments was performed by external standard calibration using authentic pigment standards (VKI, Denmark).

For the enumeration of phytoplankton cells, $200 \mathrm{~mL}$ samples were preserved with $2 \%$ (final concentration) hexamine-buffered formaldehyde. The cells were identified and enumerated using an inverted microscope (a Zeiss Axiovert 200) operating with phase contrast and bright field optics (UTERMÖHL 1958; LUND et al.,1958; VILIČIĆ et al., 2008). The references for phytoplankton identification were: HUSTEDT (1959), HASTLE \& SYVERTSEN (1997), BERARD-THERRIAULT et al., (1999) and THRONDSEN et al., (Í2007).

The chemotaxonomic correspondence of the HPLC-determined pigments (Table 1) can be used to study the composition of the phytoplankton community (STÓN et al., 2002; VILIČIĆ et al., 2008; VIDUSSI et al., 2001).

The diagnostic pigments (DP) are defined as the sum of seven diagnostic pigments.
$\mathrm{DP}=$ zea/lut + chl b+ allo $+19^{\prime}-\mathrm{HF}+19^{\prime}-\mathrm{BF}+$ fuco + peri (vidussi et al., 2001)

For data sorting, numerical and graphical processing as well as for basic statistical analysis, Microsoft Excel (Microsoft Corporation 2007), Grafer 7, Ocean Data View 4 and Statistica 7.0 computer packages were used. RDA analysis was performed using the $\mathrm{R}$ package "vegan" for community ecology and R software. In order to assess the influence of each set of environmental and chemical variables on phytoplankton abundance and the concentration of adequate pigments, a redundancy analysis (RDA) was performed. RDA calculations were based on log-transformed phytoplankton abundance in order to reduce the effect of uneven density distributions. The arrows representing explanatory variables indicated the direction of maximum change of these variables across the diagram and the cosine of the angle between the arrows gives the correlation between the corresponding explanatory variables.

Additionally, a non-parametric Spearman correlation coefficient was used to confirm correlations between phytoplankton groups or phytoplankton pigments with environmental and chemical conditions. The data were log transformed for this analysis.

\section{RESULTS}

\section{Hydrographic parameters and nutrients}

The hydrographic parameters (temperature and salinity) from weekly sampling at BK1 station (Fig. 2) showed the presence of stratifica- 
tion during the investigated period. In period from June to August, a thermocline was presented, while in the periods from February to July and October to March, the investigated area was under fresh water influence and an intensive halocline was generated, as confirmed by the coefficient of variation $(>30 \%)$ shown in Table 2.
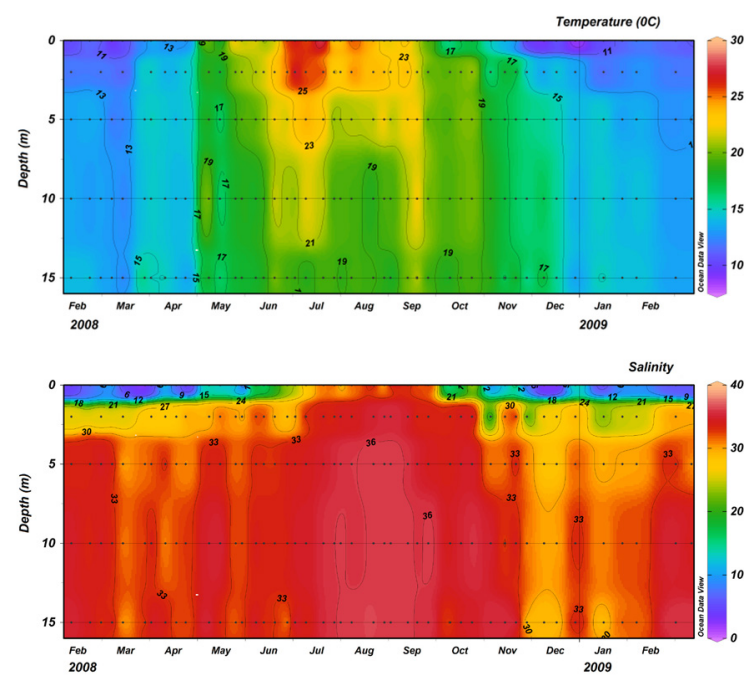

Fig. 2. Temporal variability of the temperature (a) and salinity (b) at BK1 station at weekly intervals

The temperature and salinity showed large seasonal fluctuations. The greatest mean value for temperature reached $22.32 \pm 3.91{ }^{\circ} \mathrm{C}$ in the summer and salinity was also greatest in the summer (33.01+3.79) (Table 2).

The lowest mean value of temperature was in the winter $(12.48 \pm 0.86)$ while salinity was lowest in the spring $(28.05 \pm 10.64)$ (Table 2).

Increasing median values of nutrient concentrations were detected in the spring and the autumn (Fig. 3). During the summer, nitrogen $\left(\mathrm{NO}_{2}{ }^{-}, \mathrm{NO}_{3}^{-}\right.$and NTOT) and silicate $\left(\mathrm{SiO}_{4}^{-}\right)$ concentrations were lower while total phosphate (PTOT) showed its greatest value. The temporal distribution of nutrient concentration showed significant seasonal variability $(\mathrm{p}<0.05)$ for $\mathrm{NO}_{2}{ }^{-}, \mathrm{NO}_{3}{ }^{-}, \mathrm{PO}_{4}^{-}$and $\mathrm{SiO}_{4}{ }^{-}$.

\section{Pigments and phytoplankton}

A total chlorophyll $a$ maximum was recorded at the surface, in November 2008. Chlorophyll $a$ concentrations decreased from the surface to the bottom layers (Fig. 4). The greatest median of chlorophyll a concentration was reported in April 2008.

The HPLC pigment data revealed seasonal changes in the phytoplankton community structure. Some diagnostic pigments were seen to covary with the TChl $a$ biomass, whereas some others exhibited very specific variations (Fig. 4. and Fig. 5). The water column integrated (0-25m) total chlorophyll a concentration (Tchla) was linearly related to the integrated diagnostic pigment (Figure 6). The relationship is significant $(\mathrm{r}=0.921 ; \mathrm{p}<0.001)$ which makes this diagnostic pigment a valid estimator of Tchla. In this study, fucoxanthin and alloxanthin covaried with Tchl $a$ and showed a strong significant correlation ( 0.826 and 0.776 respectively) while the other diagnostic pigments showed different seasonal variations.

The maximum fucoxanthin concentration was registered in November 2008 (1324 $\mu \mathrm{gm}^{-}$ 3). Greater concentrations of fucoxanthin did not coincide with increased diatom abundance.

Table 2. Mean, Standard Deviation and Coefficient of variation of the temperature and salinity during sampling periods at the three investigated stations

\begin{tabular}{|l|c|c|c|}
\hline Parameter & Sampling periods & Mean \pm SD & CV\% \\
\hline Temperature $\left({ }^{\circ} \mathrm{C}\right)$ & April 2008 & $14.83 \pm 0.34$ & 2.29 \\
& July 2008 & $22.32 \pm 3.91$ & 17.52 \\
& November 2008 & $17.42 \pm 1.62$ & 9.31 \\
& March 2009 & $12.48 \pm 0.86$ & 6.92 \\
\hline Salinity & April 2008 & $28.05 \pm 10.64$ & 37.94 \\
& July 2008 & $33.01 \pm 3.79$ & 11.50 \\
& November 2008 & $28.56 \pm 10.60$ & 37.12 \\
& March 2009 & $31.16 \pm 8.54$ & 27.39 \\
\hline
\end{tabular}



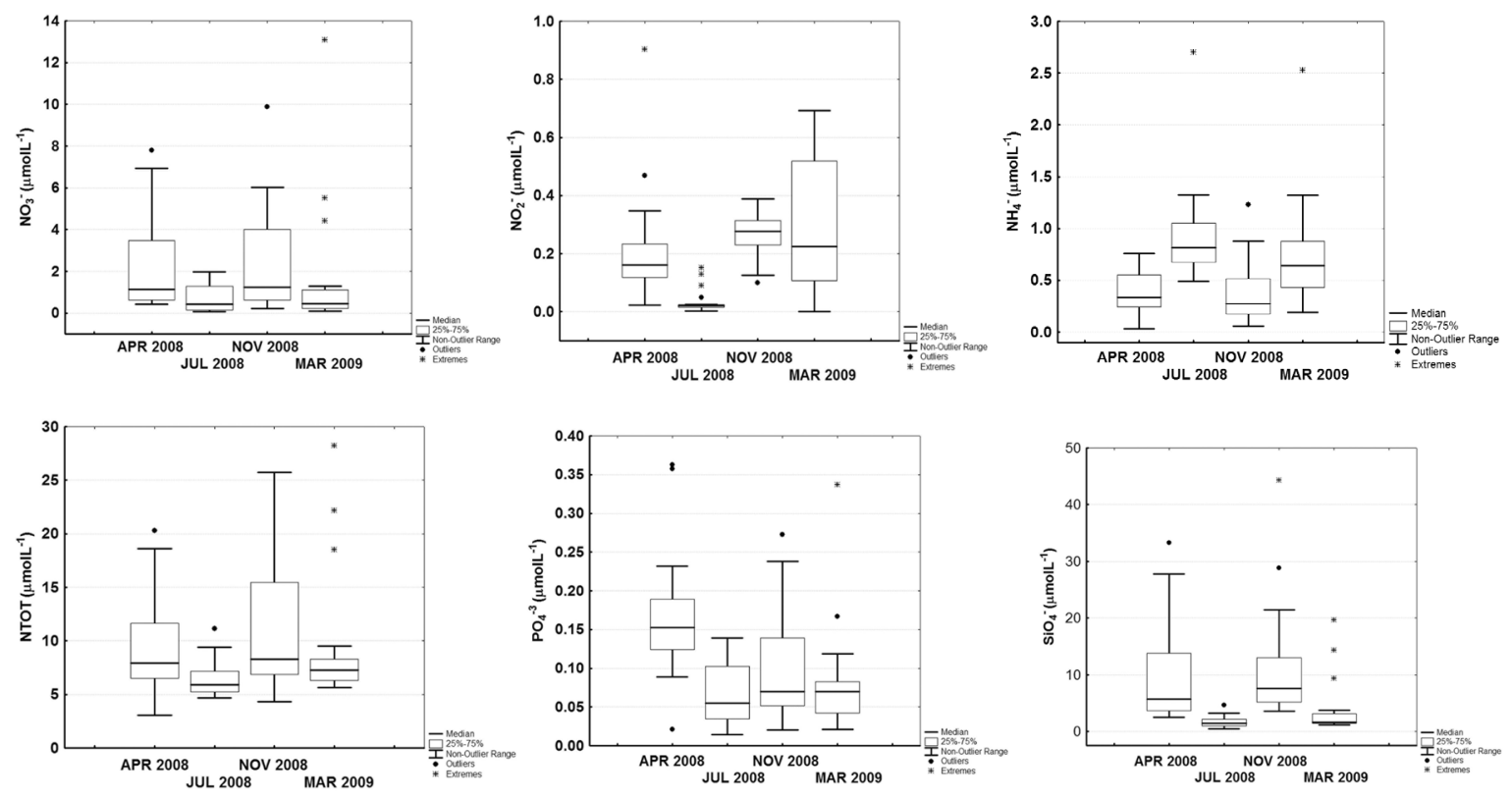

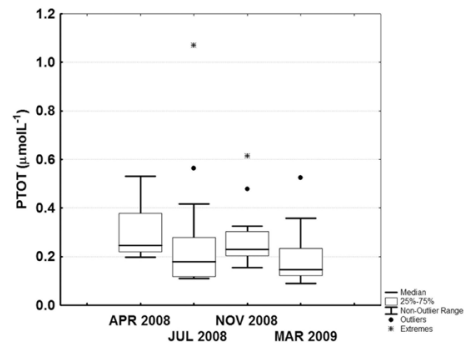

Fig. 3. Box plot diagram of seasonal distribution of a) nitrates, b) nitrites, c) ammonium, d) total nitrogen, e) phosphates, f) total phosphorus and g) silicates concentrations

The greatest diatom abundance of $2.9 \times 10^{6}$ cells $\mathrm{L}^{-1}$ was recorded in April 2008. Peridinin was recorded only in two samples, while in other samples the concentrations remained below the

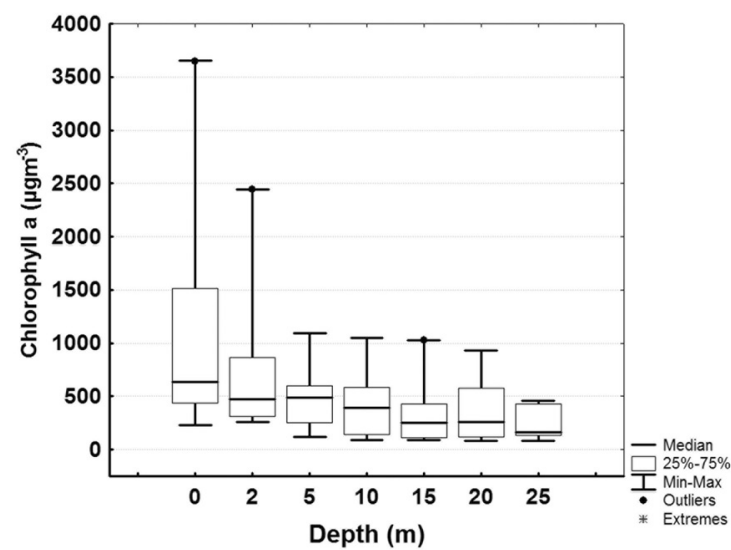

detection level. Peridinin was recorded in April 2008 and March 2009 at a depth of 2m. Dinoflagellate abundance reached its greatest values in July 2008, when peridinin was not registered. The matching pigment for coccollitophorids hexafucoxanthin increased in April 2008 while coccolithophorid abundance reached its maximum in November 2008. In April 2008, the greatest abundance of cryptophyceae coincided with the greatest concentration of alloxanthin, but its maximum concentration was recorded in the autumn. Chlorophyte abundance and chlorophyll $b$ concentration reached a maximum during the winter.

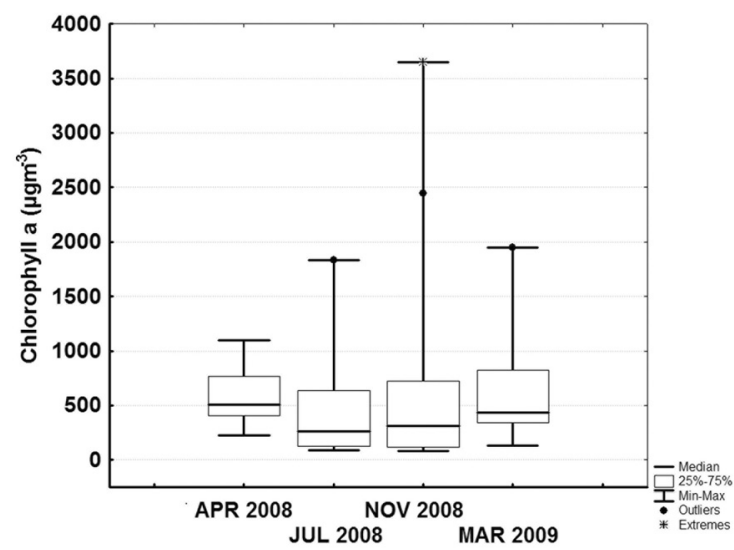

Fig. 4. Box plot diagram of chlorophyll a concentration by a) sampling periods and b) depth 

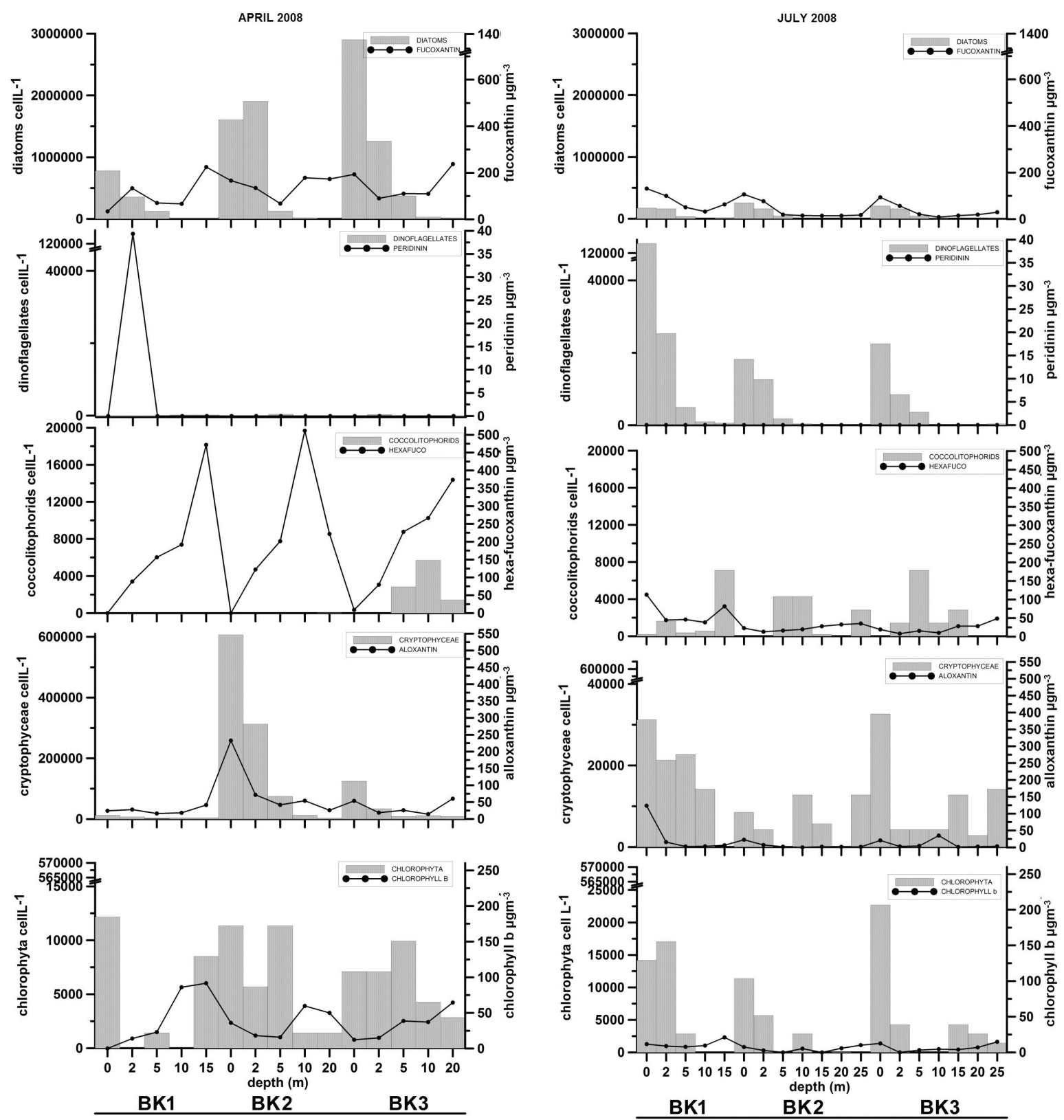

(Fig. 5. Distribution of phytoplankton abundance and biomarker pigments in Boka Kotorska Bay over four sampling periods (April 2008; July 2008; November 2008; March 2009) stavite prvo Nov 2008 pa Mart 2009)

The abundance of phytoplankton groups and the concentration of adequate pigments was partly explained by the hydrographic and chemical variables considered in the RDA analysis (Fig. 7 a and Fig. 7 b).

The first two axes of the ordination analysis explained $26.99 \%$ of the phytoplankton group abundances and $55.99 \%$ of the pigment concen- trations. The contributions of the axes were not equal, as indicated by their eigenvalues $(0.357$ and 0.174 for the phytoplankton groups and 2.21 and 1.59 for the phytoplankton pigments respectively, for axes 1 and axes 2). The analysis captured $100 \%$ of the phytoplankton groups and pigment variations that could be explained by the considered variables. The main explana- 

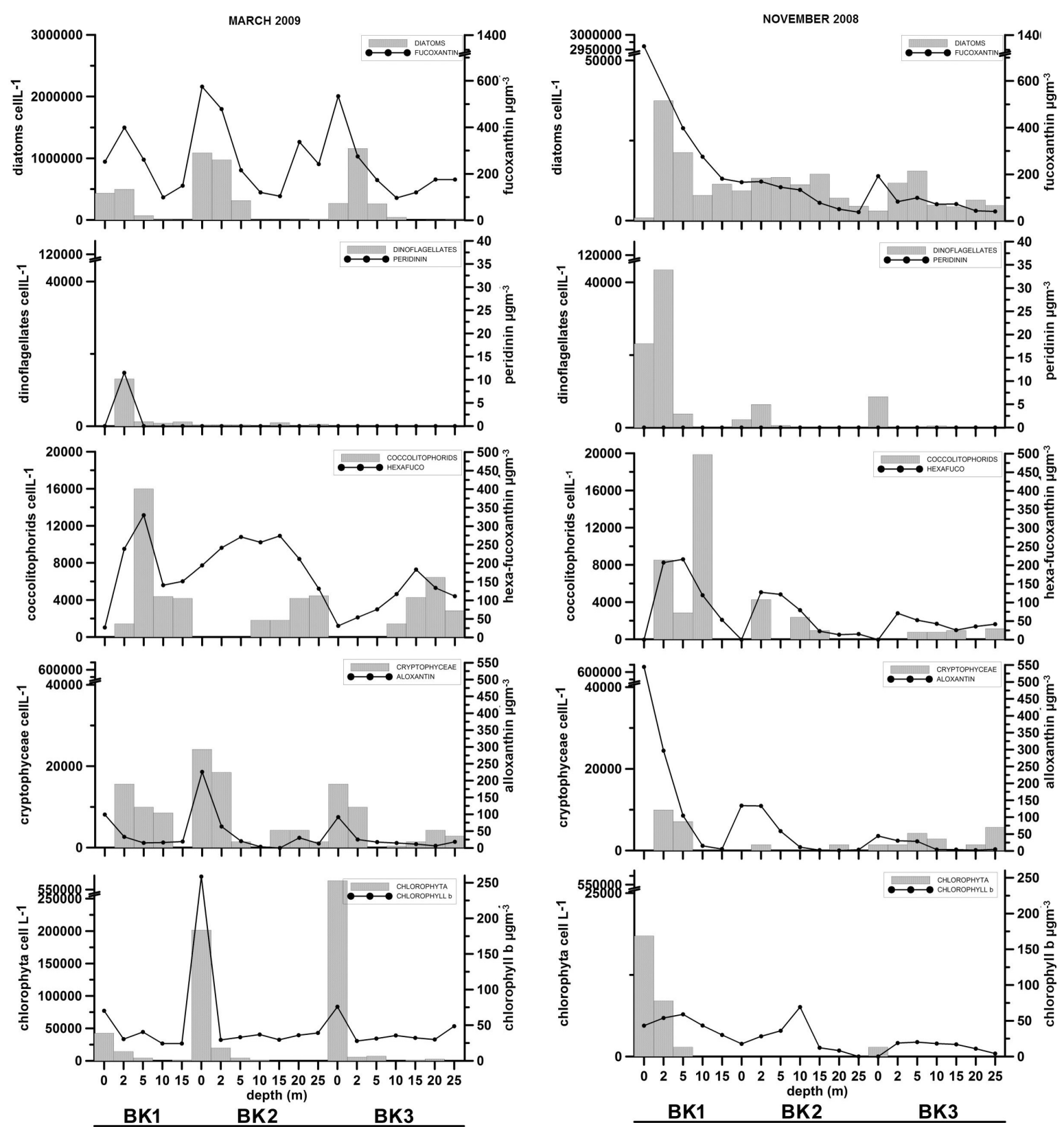

Fig. 5. Distribution of phytoplankton abundance and biomarker pigments in Boka Kotorska Bay over four sampling periods (April 2008; July 2008; November 2008; March 2009)

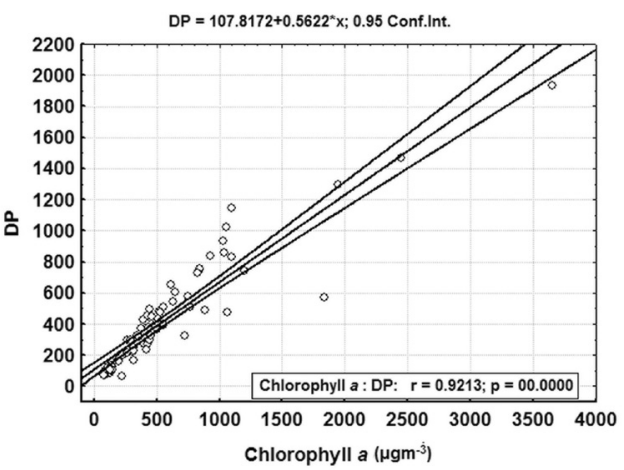

Fig. 6. Relationship between the water column integrated $0-25 m$ concentration of total chlorophyll $a$ and the diagnostic pigment (DP). 

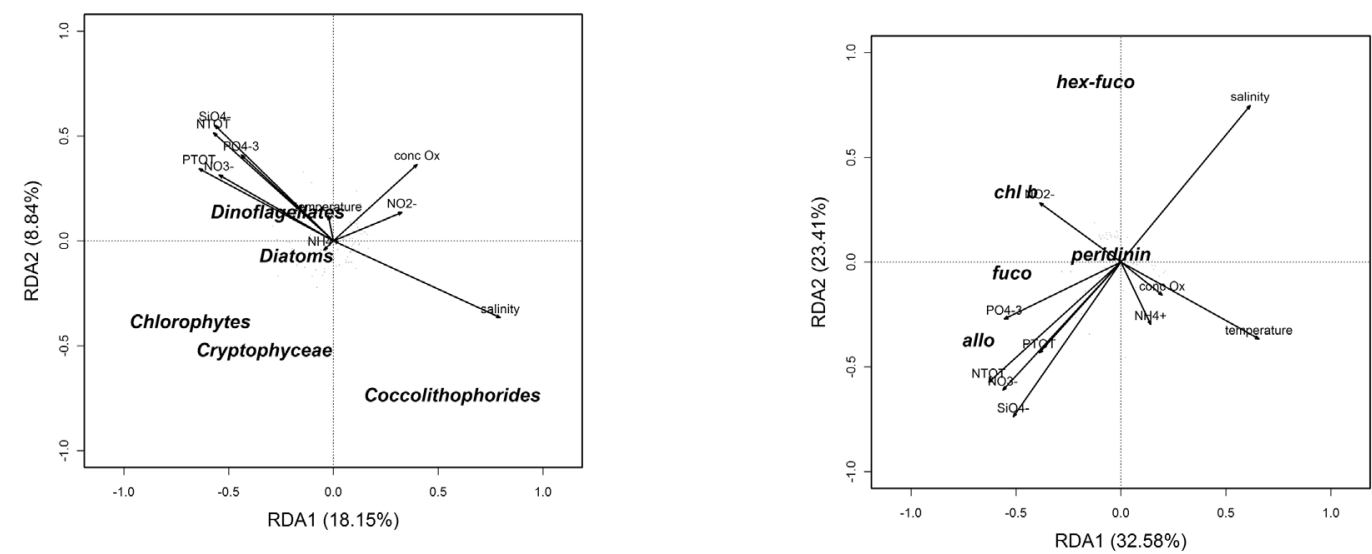

Fig. 7. Redundancy analysis (RDA) showing the bi-dimensional ordination of a) phytoplankton groups and b) phytoplankton pigments. Superimposed vectors represent explanatory variables: temperature, salinity, oxygen concentration (Ox), nutrients (SiO4-, PO4-3, NO3-, NO2-, PTOT, NTOT). In order to make their scales comparable, both biological and hydrological variables were scaled to unit variance.

Table 3. Spearman's rank order correlation of physic-chemical parameters with a) phytoplankton groups and b) phytoplankton pigments $(p<0.05 ; n=68)$

a)

\begin{tabular}{|c|c|c|c|c|c|}
\hline Variables & Diatoms & Dinophlagellates & Coccolitophorides & Criptophyceae & Chlorophyta \\
\hline Temperature & -0.18 & $\mathbf{0 . 3 4}$ & $\mathbf{- 0 . 3 7}$ & -0.06 & -0.18 \\
\hline Salinity & $\mathbf{- 0 . 5 4}$ & -0.15 & $\mathbf{0 . 3 7}$ & $\mathbf{- 0 . 4 4}$ & $\mathbf{- 0 . 3 3}$ \\
\hline Conc $\mathrm{O}_{\mathrm{x}}$ & $\mathbf{- 0 . 4 2}$ & -0.12 & 0.09 & $\mathbf{- 0 . 3 0}$ & -0.15 \\
\hline $\mathrm{NO}_{3}^{-}$ & $\mathbf{0 . 4 7}$ & -0.02 & $\mathbf{0 . 3 1}$ & $\mathbf{0 . 3 8}$ & 0.23 \\
\hline $\mathrm{NO}_{2}^{-}$ & -0.08 & -0.12 & $\mathbf{0 . 2 6}$ & -0.06 & -0.05 \\
\hline $\mathrm{NH}_{4}^{-}$ & 0.01 & 0.05 & -0.11 & -0.01 & 0.23 \\
\hline $\mathrm{NTOT}^{-}$ & $\mathbf{0 . 4 1}$ & 0.09 & $\mathbf{- 0 . 3 0}$ & $\mathbf{0 . 3 1}$ & $\mathbf{0 . 3 4}$ \\
\hline $\mathrm{PO}_{4}^{-3}$ & $\mathbf{0 . 4 5}$ & 0.08 & -0.22 & $\mathbf{0 . 4 5}$ & 0.10 \\
\hline $\mathrm{PTOT}^{-3}$ & $\mathbf{0 . 3 1}$ & $\mathbf{0 . 3 7}$ & $\mathbf{- 0 . 2 8}$ & $\mathbf{0 . 2 8}$ & 0.12 \\
\hline $\mathrm{SiO}_{4}^{-}$ & $\mathbf{0 . 4 8}$ & 0.00 & $\mathbf{0 . 3 3}$ & $\mathbf{0 . 4 9}$ & 0.09 \\
\hline
\end{tabular}

b)

\begin{tabular}{|c|c|c|c|c|c|}
\hline Variables & fuco & peridinin & hex-fuco & allo & chl $b$ \\
\hline Temperature & $\mathbf{- 0 . 3 5}$ & -0.10 & $\mathbf{- 0 . 4 9}$ & -0.18 & $\mathbf{- 0 . 4 5}$ \\
\hline Salinity & $\mathbf{- 0 . 4 7}$ & -0.03 & 0.22 & $\mathbf{- 0 . 6 5}$ & $\mathbf{- 0 . 2 5}$ \\
\hline $\mathrm{Conc}_{\mathrm{x}}$ & 0.21 & 0.05 & -0.18 & 0.20 & -0.10 \\
\hline $\mathrm{NO}_{3}^{-}$ & $\mathbf{0 . 3 8}$ & -0.01 & -0.20 & $\mathbf{0 . 5 4}$ & $\mathbf{0 . 2 6}$ \\
\hline $\mathrm{NO}_{2}^{-}$ & 0.19 & -0.14 & 0.21 & 0.06 & 0.17 \\
\hline $\mathrm{NH}_{4}^{-}$ & 0.11 & -0.09 & $\mathbf{- 0 . 2 7}$ & 0.15 & 0.03 \\
\hline $\mathrm{NTOT}^{-}$ & $\mathbf{0 . 4 7}$ & 0.03 & -0.18 & $\mathbf{0 . 5 9}$ & $\mathbf{0 . 3 8}$ \\
\hline $\mathrm{PO}_{4}^{-3}$ & 0.19 & $\mathbf{0 . 3 7}$ & -0.03 & $\mathbf{0 . 4 2}$ & $\mathbf{0 . 2 5}$ \\
\hline $\mathrm{PTOT}^{-3}$ & $\mathbf{0 . 3 4}$ & 0.11 & -0.14 & $\mathbf{0 . 4 8}$ & 0.11 \\
\hline $\mathrm{SiO}_{4}^{-}$ & $\mathbf{0 . 4 0}$ & 0.06 & -0.20 & $\mathbf{0 . 6 0}$ & 0.14 \\
\hline
\end{tabular}


tory variable is salinity, which showed a strong positive correlation with coccolithophorides and a strong negative correlation with diatoms, cryptophytes and chlorophytes. These phytoplankton groups followed an inverse trend with the nutrients $\left(\mathrm{SiO}_{4}^{-}, \mathrm{NO}_{3}^{-}, \mathrm{NTOT}\right.$, PTOT, $\left.\mathrm{PO}_{4}^{-3}\right)$ when compared with salinity. Adequate pigments concentrations had a similar relationship with the explanatory variables but it was weaker than for the phytoplankton groups. The second explanatory variable is temperature, which shows a positive trend only with dinoflagellates among the phytoplankton groups and a negative correlation with all the phytoplankton pigments except peridinin. These results were confirmed by the nonparametric Spearman correlation coefficient (Table 3).

\section{DISCUSSION}

The redundancy analysis (RDA) showed that salinity represents the main environmental factor influencing the distribution of the main phytoplankton groups. Salinity was $<30$ in the whole water column during November and December as well as at depths greater than $5 \mathrm{~m}$ for most of the year. The distribution of coccolithophorides along the salinity gradient is presented as a negative correlation. The same was found by OVIEDO et al. (2015) across the Mediterranean, including the South Adriatic. Coocolithophorides are of marine origin in Boka Kotorska Bay and usually distributed as a nano size fraction below the halocline, as was the case in previous research (BOSAK et al., 2012). Other taxa can tolerate lower salinity. Regarding diatoms, there was a negative correlation with salinity (also seen in BALZANO et al., 2010, ADENAN et al., 2013, TOTTI et al., 2000). A negative correlation with salinity was characteristic of chlorophytes (also seen in NASSAR et al. 2014) for the southern Mediterranean coast. Cryptophytes correlated negatively with salinity and Dynobrion sp. preferred the upper, nutrient rich and less saline layer (as was also found in BOSAK et al., 2012).

The concentration of nutrients in Boka Kotorska Bay was generally higher in April 2008 and November 2008 and favorable for phytoplank- ton development, especially that of diatoms in April 2008. Negative correlations between salinity and the main nutrients indicated that nutrients entered the sea by freshwater inflow. In this study, the maximum chlorophyll $a$ concentration was recorded in November 2008. These results coincided with trends in the northern Adriatic where greater values of chlorophyll $a$ concentration were registered in the whole water column in the autumn (MOZETIČ et al 1998; TEDESCO et al. 2007; MOZETIČ et al 2010), and in the middle Adriatic basin (TOTTI et al., 2000) and the southern Adriatic (KORLEVIĆ et al., 2015).

As is generally known from the Adriatic, the most dominant biomarker pigment throughout the investigated area were fucoxanthin (VILIČIĆ et al. 2008) and alloxanthin (ŠUPRAHA et al. 2014) which was very well correlated with chlorophyll $a$. Microscopic analysis confirmed diatoms as the most numerous microphytoplankton group, as was reported previously in Spanish estuaries (ANSOTEGUI et al., 2001; SEOANE et al., 2005) as well as in the Black Sea (AGIRBAS et al., 2017). The greatest abundances of diatoms are normally observed during the spring and the autumn in the Adriatic Sea (TOTTI et al., 2000).

The correlation between the determined diatom cell density and fucoxanthin was good $(p=0.009)$, once a few outliers were ignored. The concentration of fucoxanthin was found to be greatest in November 2008 which is similar to data noted for the Black Sea (AGIRBAS et al., 2017) where greater values were found during the spring and the autumn, while it differs from the data given by ANSOTEGUI et al. (2003) when the greatest fucoxanthin concentration was in the late winter-early spring period in the estuaries of the Spanish coastline. These findings might support the idea that the spatio-temporal distribution of the phytoplankton community is closely related to its environmental conditions (e.g. nutrients, light and so on) as was reported by BUZANČIĆ et al., (2016).

Pigments concentrations in the cells normally vary with different light quality and intensity, nutrients availability and the physiological status of the cell (MOROVIĆ et al., 2012). A weak presence of peridinin was detected in 
the HPLC analysis, which eluted in very low concentrations, although a large population of dinoflagellates was found by microscopy. The dinoflagellate species composition from the same period of research has been presented by BOSAK et al. (2012). The discrepancy between peridinin concentration and dinoflagellate abundance may be caused either by the dominance of heterotrophic dinoflagellate species (LORET et al., 2000), such as Protoperidinium spp. or Diplopsalis spp. (BOSAK et al., 2012) or the presence of dinoflagellates that possess plastids containing phycobilin rather than peridinin, such as one of the dominant genera Dinophysis spp. (TAKISHITA et al., 2002).

In November 2008, the diatoms were outcompeted by coccolithophorids, probably due to the lower supply of nutrients and their efficient absorption by coccolithophorids (FURNAS, 1990). Coccolithophorids characteristic of coastal and brackish areas contain chlorophyll $\mathrm{C}_{1}$ rather than hexa-fucoxanthin. Taxa that contain hexafuco, are always characteristic of open-coastal, rather than littoral, locations (VAN LENNING et al., 2004). It may be for this reason that, in this paper, the concentrations of hex-fuco were lower than those of fucoxanthin and alloxanthin. This pigment, however, proved to be a very good indicator of the influence of the salinity gradient on phytoplankton composition. Hex-fuco increased with increasing salinity, clearly indicating a marine origin of the species carrying this pigment - probably prymnesiophytes (ZAPATA et al., 2004). This is proved in the current paper where salinity showed a positive correlation with coccolithophorids and hexa fucoxanthin.

The correlation of cryptophytes with alloxanthin was similar with correlation in the eastern Adriatic, Zrmanja estuary (VILIČIĆ et al., 2008), where it was noticed compatibility between abundances of cryptophytes and concentration of alloxanthin above halocline in winter season and below halocline in summer season. Cryptophytes containing alloxanthin were found in a greater concentration in April 2008 and a maximum concentration in November 2008, mainly in the surface layer. A greater concentration of alloxanthin and an abundance of cryptophytes was also recorded in the surface layer of the Krka estuary (ŠUPRAHA et al., 2014). The shift from diatom-dominant blooms to cryptophytes-dominant bloom confirms the hypothesis that the phytoplankton community is undergoing changes due to eutrophication (ŠUPRAHA et al., 2014) and that cryptophytes are the more dominant group in anthropogenically - influenced area. The noted correlation between salinity on the one hand and cryptophytes and alloxanthin on the other was negative. A similar situation was noticed where cryptophytes containing alloxanthin were found mainly at lower salinities (18-35), with their maxima in the surface layer of the middle estuary and below the halocline in the upper estuary (VILIČIIĆ et al., 2008).

Chlorophyll $b$ as pigment contained by chlorophytes was greatest in March 2009, which is different from the results given by ANSOTEGUI et $a l$. (2003) where $\mathrm{Chl} b$ followed a clear seasonal pattern, with its greatest values during warmer periods, and increasing after the winter-spring transition. The noted correlation between chlorophyte abundance and chlorophyll b concentration and temperature was negative.

\section{CONCLUSION}

Boka Kotorska Bay represents a collector of the freshwater supply coming from the springs and karstic structures along its border. Higher concentrations of nutrients in spring and autumn are favorable for phytoplankton development, and most especially diatom growth in the spring. The phytoplankton assemblages were composed of microphytoplanktonic diatoms, as well as nanoplanktonic/ picoplanktonic cryptophytes, dinoflagellates, prymnesiophytes, and chlorophytes (SIEBURTH et al., 1978). The predominant biomarker throughout the investigated area was fucoxanthin, with the greatest concentration in the autumn. It seems that this differs from the point of greatest diatom abundance (in the spring) which can be accounted for by the fact that the peak of fucoxanthin may have originated from nanoplanktonic non-diatom species. Coccolithophorids dominated in the autumn, which differs from the peak of adequate hexfuco pigment that was greatest in the spring. 


\section{ACKNOWLEDGEMENTS}

The Norwegian Cooperation Program on Research and Higher Education funded this study with the countries of the Western Balkans through the project: Marine science and coastal management in the Adriatic, Western Balkans, an education and research network (2006-2009). The authors gratefully acknowledge Dr. Marijan Ahel (Ruđer Bošković Institute, Croatia), in whose laboratory the HPLC analysis of the phytoplankton pigments was performed.

\section{REFERENCES}

ADENAN, N.S., YUSOFF, F. MD. \& M. SHARIFF 2013. Effect of salinity and temperature on the growth of diatoms and green algae. Journal of Fisheries and Aquatic Science, 8(2): $397-$ 404.

AGIRBAS, E., KOCA, L. \& A.ULGAN 2017. Spatio- temporal pattern of phytoplankton and pigment composition in surface waters of south-eastern Black Sea. Oceanologia 59(3): 283-299.

AHEL, M. \& S. TERZIĆ. 1998. Pigment signatures of phytoplankton dynamics in the northern Adriatic. Croatica Chem. Acta, 71(2): 199215.

ANSOTEGUi, A., A. SAROBE, J.M. TRIGUEROS, I. URRUTXURTU \& E. ORIVE 2003. Size distribution of algal pigments and phytoplankton assemblages in a coastal-estuarine environment contribution of small eukaryotic algae. Journal of Plankton Research, 25(4): 341355.

ANSOTEGUI, A., J.M. TRIGUROS \& E. ORIVE. 2001. The use of pigment signatures to assess phytoplankton assemblage structure in estuarine waters. Estuarine Coastal and Shelf Science, 52(6): 689-703.

ARAUJO, M.L.V., MENDES, C.RR.B., TAVANO, V.M., GARCIA, C.A.E \& M.O. BERINGER 2017. Contrasting patterns of phytoplankton pigments and chemotaxonomic groups along $30^{\circ} \mathrm{S}$ in the subtropical South Atlantic Ocean. Deep Sea Research. Part I: OceanographicResearch Papers. 120: 112-121.

BALZANO, S., SARNO, D. \& W. H.C.F.KOOISTRA 2011. Effects of alinity on the growth rate and morphology of ten Sceletonema strains. Journal of Plankton Research, 33(6): 937-945.

BARLOW, R., M. KYEWALYANGA, H. SESSIONS, M.
VAN DEN BERG \& T. MORRIS 2008. Phytoplankton pigments, functional types, and absorption properties in the Delagoa and Natal Bights of the Agulhas ecosystem. Estuarine Coastal Shelf Science, 80: 201-211.

BARLOW, R.G, R.F.C. MANTOURA, M.A. GOUGH \& T.W. FILIMAN. 1993. Pigment signatures of the phytoplankton composition in the northeastern Atlantic during the 1990 spring bloom. Deep-Sea Res. II, 40(1-2): 459-477.

BELlAFIORE, D., A. GUARNIERI, F. GRILLI, P. PENNA, G. BORTOLUZZI, F. GIGLIO \& N. PINARDI. 2011. Study of the hydrodynamical processes in the Boka Kotorska Bay with a finite element model. Dynamics of Atmospheres and Oceans, 52(1-2): 298-321.

BERARD-THERRIAULT, L., M. POULIN \& L. BOSSE. 1999. Guide d'identification du phytoplancton marin de l'estuarie et du golfe du SaintLaurent incluant 'egalement certains protozoaires, (Guide to the identifying marine phytoplankton of the estuary and gulf of St. Lawrence including certain protozoans), Publ. Sp'ec. Canad. Sci. Halieut. Aquatiq., Ottawa, 387 pp.

BOSAK, S., T. ŠILOVIĆ, Z. LJUBEŠIĆ, G. KUŠPILIĆ, B. PESTORIĆ, S. KRIVOKAPIĆ \& D. VILIČIĆ. 2012. Phytoplankton size structure and species composition as an indicator of trophic status in transitional ecosystems: the case of a Mediterranean fjord-like karstic bay. Oceanologia, 54 (2): 255-286.

BUŽANČIĆ, M., Ž. NINČEVIĆ GLADAN, I. MARASOVIĆ, G. KUŠPILIĆ \& B. GRBEC. 2016. Eutrophication influence on phytoplankton community composition in three bays on the eastern Adriatic coast. Oceanologia, 58: 302-316. 
CARRETO, J. I., N. G. MONTOYA, H. R. BENAVIDES, R. GUERRERO \& M. O. CARIGNAN 2003. Characterization of spring phytoplankton communities in the Rio de La Plata maritime front using pigment signatures and cell microscopy. Marine Biology, 143: 1013-1027.

CAMPANElli, A., A. BUlatoviĆ, M. CABRINI, F. GRILLI, Z. KLJAJIĆ, R. MOSETTI, E. PASHINI, P. PENNA \& M. MARINI. 2009. Spatial distribution of physical, chemical and biological oceanographic properties, phytoplankton, nutrients and Coloured Dissolved Organic Matter (CDOM) in the Boka Kotorska Bay (Adriatic Sea). Geofizika, 26(2): 215-228.

COUPEL, P., MATSUOKA, A., RUIZ-PINO, D., GOSSELIN, M., MARIE, D., TREMBLAY, J.-E. \& M. BABIN. 2015. Pigment signatures of phytoplankton communities in the Beaufort Sea. Biogeosciences, 12: 991-1006.

DAUTOVIĆ, J., S. STRMEČKI, B. PETROVIĆ, V. VOJVODIĆ, M. PLAVŠIĆ, S. KRIVOKAPIĆ \& B. ĆOSOVIĆ. 2012. Organic matter in the karstic enclosed bay (Boka Kotorska Bay, south Adriatic Sea). Fresenius environmental bulletin, 21 (4a): 995-1006.

DRAKUlOVIĆ, D., B. PESTORIĆ, M. CVIJAN, S. KRVOKAPIĆ \& N. VUKSANIVIĆ. 2012. Distribution of phytoplankton community in Kotor Bay (south-eastern Adriatic Sea). Central European Journal of Biology, 7(3): 470-486.

DRAKULOVIĆ, D., B. PESTORIĆ, R. KRAUS, S. LJUBIMIR \& S. KRIVOKAPIĆ. 2016. Phytoplankton community and trophic state in Boka Kotorska Bay. In: A. Joksimovic' et al. (Editors). The Boka Kotorska Bay Environment, Hdb Env Chem, DOI 10.1007/698_2016_30, Springer International Publishing Switzerland 2016

FURNAS, M. 1990. In situ growth rates of marine phytoplankton: approaches to measurement, community and species growth rates. Journal of Plankton Research, 12(6): 1117-1151.

HASTLE, G.R. \& E.E. SYVERTSEN. 1997. Marine diatoms. In: Identifying marine diatoms and dinoflagellates. Thomas, C. R. (eds.), Academic Press, San Diego, 5-385.

HUSTEDT, F. 1959. The diatoms of Germany, Austria and Schweitz (Die Kieselalgen
Deutschlands, Österreichs und der Schweitz), Otto Koeltz, Scientific Publishing, Koenigstein, (in German)

IHMZ, Institute for Hydrometeorology and Seismology of Montenegro, http://www.meteo. co.me/

JEFFREY, S.W., R.F.C. MANTOURA \& S.W. WRIGHT. 1997. Phytoplankton pigments in Oceanography. UNESCO, Paris. pp 261

KORLEVIĆ, M., RISTOVA, P., GARIĆ, R., AMANN, R. \& ORLIĆ, S. 2015. Bacterial diversity in the south Adriatic Sea during a strong, deep winter convection year. Applied and Environmental Microbiology, 81(5): 1715-1726.

KRIVOKAPIĆ, S., B. PESTORIĆ, G. KUŠPILIĆ, S. BOSAK \& C. WEXELS RISER. 2011. Trophic state of Boka Kotorska Bay (Eastern Adriatic Sea). Fresenius Environmental Bulletin, 20(8): 1960-1969.

KRIVOKAPIĆ, S., Ž. STANKOVIĆ \& N. VUKSANOVIĆ. 2009. Seasonal variation of phytoplankon biomass and environmental conditions in the inner Boka Kotorska Bay (eastern Adriatic Sea). Acta Botanica Croatica, 68(1): 45-55.

LEWITUS, A.J., D.L. WHITE, R.G. TYMOWSKI, M.E. GEESEY, S.N. HYMEL \& P.A. NOBLE. 2005. Adapting the CHEMTAX method for assessing phytoplankton taxonomic composition in southeastern U.S. estuaries. Estuaries, 28(1): 160-172.

LORET, P., A. PASTOUREAUd, C. BACHER \& B. DELESALLE. 2000. Phytoplankton composition and selective feeding of the pearl oyster Pinctada margaritifera in Takapoto lagoon (Tuamotu Archipelago, French Polynesia): in situ study using optical microscopy and HPLC pigment analysis. Marine Ecology Progress Series, 199: 55-67.

LUND, J.W.G., C. KIPLING \& E.D.L. CREN. 1958. The inverted microscope method of estimating algal numbers, and the statistical basis of estimation by counting, Hydrobiologia, 11(2): 143-170.

MACKEY M. D., D. J. MACKEY, H. W. HIGGINS \& S. W. WRIGHT 1996. CHEMTAX - A program for estimating class abundances from chemical markers: application to HPLC measurements of phytoplankton. Marine Ecology Progress Series, 144: 265-283. 
MADHU, N.V., ULLAS, N., ASHWINI, R., MEENU, P., REHITHA, T.V. \& K.R. LALLU. 2014. Characterization of phytoplankton pigments and functional community structure in the Gulf of Mannar and the Palk Bay using HPLC-CHEMTAX analysis. Continental Shelf Research, 80: 79-90.

MARINI, M., A. CAMPANELLI, M. SANXHAKU, Z. KLJAJIĆ, M. BETTI \& F. GRILLI. 2015. Late spring characterization of different coastal areas of the Adriatic Sea. Acta Adriat, 56(1): 27-46.

MENDES, C.R., S.A. CAROLINA, J. VITORINO, C. BORGES, V.M.T. GARCIJA \& V. BROTAS. 2011. Spatial distribution of phytoplankton assemblages in the Nazaré ubmarine canyon region (Portugal): HPLC-CHEMTAX approach. Journal of Marine Systems, 87: 90-100.

MENDES, C.R., KERR, R., TAVANO, V.M., CAVALHEIRO, F.A., GARCIA, C.A.E. \& D.R.G DESSAI. 2015. Cross-front phytoplankton pigments and chemotaxonomic groups in the Indian sector of the Southern Ocean. Deep-Sea Research II, 118(B): 221-232.

MOROVIĆ, M., FLANDER PUTRLE, V., LUČIĆ, D., GRBEC, B., GANGAI, B., MALEJ, A. \& F. MATIĆ 2012. Signatures of pigments and processes in the south Adriatic Pit- project MEDUZA. Acta Adriat., 53(2): 303-322.

MOZETIČ, P., FONDA UMANI, S., CATALETTO, B., MALEJ, A. 1998. Seasonal and ter-annual plankton variability in the Gulf of Trieste (Northern Adriatic). ICES Journal of Marine Sciences, 55: 711-722.

MOZETIČ, P., SOLIDORO, C., COSSARINI, G., SOCAL, G., PRECALI, R., FRANCE, J., BIANCHI, F., DE VITTOR, C., SMODLAKA, N \& S. FONDA UMANI 2010. Recent trends towards oligotrophication of the northern Adriatic: Evidence from chlorophyll $a$ time series. Estuaries and Coasts, 33: 362-375.

NASSAR, M. Z., HAMDY R. M., KHAIRY H. M. \& S.H. RASHEDY 2014. Seasonal fluctuations of phytoplankton community and physico-chemical parameters of the north western part of the Red Sea, Egypt. Egyptian Journal of Aquatic Research, 40(4): 395-403.

OVIEDO, A., ZIVERI, P., ÁLVAREZ, M.\& T TANHUA
2015. Is coccolithophore distribution in the Mediterranean Sea related to seawater carbonate chemistry? Ocean Science, 11: 13-32. RIMET, F. \& A. BOUCHEZ. 2012. Biomonitoring river diatoms: implications of taxonomic resolution. Ecological Indicators, 15(1): 92-99.

SEOANE, S., A. LAZA, I. URRUTXURTU \& E. ORIVE. 2005. Phytoplankton assemblages and their dominant pigments in the Nervion River estuary. Hydrobiologia, 549(1): 1-13.

SIEBURTH, N., SMETACEK, V., \& J. LENZ 1978. Pelagic ecosystem structure: Heterotrophic compartments of the plankton and their relationship to size fractions. Limnology and Oceanography, 23(6): 1256-1263.

STÓN, J., A. KOSAKOWSKA \& M. LOTOCKA. 2002. Pigment composition in relation to phytoplankton community structure and nutrient content in the Black Sea. Oceanologia, 44(4): 419-437.

STRICKLAND, J.D.H. \& T.R. PARSONS. 1972. A Practical Handbook of Seawater Analysis. Bull. Fish. Res. Board Can., 167, 310pp.

ŠUPRAHA, L., S. BOSAK, Z. LJUBEŠIĆ, H. MIHANOVIĆ, G. OLUJIĆ, I. MIKAC \& D. VILIČIĆ. 2014. Cryptophyte bloom in a Mediterranean estuary: High abundance of Plagioselmis cf. prolonga in the Krka River estuary (eastern Adriatic Sea). Scientia Marina, 78(3): 329338.

TAKISHITA, K., KOLKE, K., MARUYAMA, T., \& T. OGATA. (2002). Molecular evidence for plastid robbery (kleptoplastidy) in Dinophysis, a dinoflagellate causing diarrhetic shellfish poisoning. Protist, 153(3): 293-302.

TEDESCO, L., G. SOCAL, F. BIANCHI, F. ACRI, D. VENERI \& M. VICHI. 2007. NW Adriatic Sea variability in relation to chlorophyll $a$ dynamics in the last 20 years (1986-2005). Biogeosciences, 4: 651-685.

TOTTI, C., CIVITARESE, G., ACRI, F., BARLETTA, D., CANDELARI, G., PASCHINI, E. \& A. SOLAZZI 2000. Seasonal variability of phytoplankton populations in the middle Adriatic sub-basin. Journal of Plankton Research, 22(9): 17351756.

THRONDSEN, J., G.R. HASLE \& K. TANGEN. 2007. Phytoplankton of Norwegian coastal waters,. Almater Forlag As, Oslo, 343pp. 
UTERMÖHL, H. 1958. Zur Vervollkommung der quantitativen Phytoplankton Methodik. Mitt. Int Ver Theor Angew Limnol., 9: 1-38.

VAN LENNING, K., PROBERT, I., LATASA, M., ESTRADA, M., \& J.R. YOUNG. 2004. Pigment diversity of coccolithophores in relation to taxonomy, phylogeny and ecological preferences. In: Coccolithophores. Springer Berlin Heidelberg, pp. 51-73.

VIDUSSI, F., H. CLAUSTRE, B.M. BENIAMINO, A. LUCHETTA \& M. JEAN-ClAUde. 2001. Phytoplankton pigment distribution in relation to upper thermocline circulation in the eastern Mediterranean Sea during winter. Journal of Geophysical Research, 106(C9): 1993919956.
VILIČIĆ, D., S. TERZIĆ, M. AHEL, Z. BURIĆ, N. JASPRICA \& M. CARIĆ. 2008. Phytoplankton abundance and pigment biomarkers in the oligo-trophic eastern Adriatic estuary. Environ. Monit. Assess., 142 (1-3): 199-218.

WRIGHT, S.W. \& S.W. JEFFREY. 2006. Pigment markers for phytoplankton production. In: Volkmann, J.K. (Editors). Marine Organic Matter: Biomarkers, Isotopes and DNA. Springer-Verlag, Berlin, pp. 71-104.

ZAPATA, M., S.W. JEFFREY, S.W. WRIGHT, F RODRIGUEZ, J.L. GARRIDO \& L. CLEMENTSON. 2004. Photosynthetic pigments in 37 species (65 strains) of Haptophyta: Implications for oceanography and chemotaxonomy. Marine Ecology Progress Series, 270: 83-102. 


\title{
Raspodjela algalnog pigmenta i fitoplanktonskih zajednica u obalnom prijelaznom okruženju - Boka Kotorska (jugoistočni Jadran)
}

\author{
Slađana KRIVOKAPIĆ, Sunčica BOSAK, Damir VILIČIĆ, Grozdan KUŠPILIĆ, \\ Dragana DRAKULOVIĆ i Branka PESTORIĆ* \\ *e-pošta: brankap@ac.me
}

\begin{abstract}
SAŽETAK
Prisutnost zajednica fitoplanktona i rasprostranjenost pigmenata utvrđivani su u tranzicijskim vodama Bokokotorskog zaljeva. Uzorci su prikupljeni četiri puta na tri lokaliteta u unutrašnjosti Zaljeva u periodu između travnja 2008. i ožujka 2009. godine. Mikroskopskom analizom utvrđeno je da fitoplankton čine morske dijatomeje, dinoflagelati, kriptofiti, klorofiti i kokolitoforidi. Pored fukoksantina kao dominantnog biomarkerskog pigmenta, bili su zastupljeni i aloksantin, 19'-heksanoiloksifukoksantin, peridinin i klorofil $b$. Fukoksantin i aloksantin su pokazali značajnu korelaciju sa klorofilom $a$ kao indikatorom biomase fitoplanktona tijekom čitavog perioda ispitivanja. U studenom 2008. godine, dijatomeje su nadjačale kokolitoforide, koji su vjerovatno efikasno apsorbirali nutrijente tijekom perioda u kojem je njihova dostupnost bila smanjena. Kao rezultat smanjenog unosa nutrijenata, u ljetnom periodu, zajednicu fitoplanktona u Bokokotorskom zaljevu sačinjavali su uglavnom morski dinoflagelati, kriptofiti i klorofiti.
\end{abstract}

Ključne riječi: raspodjela pigmenta, fitoplanktonska zajednica, Bokokotorski zaljev 